\title{
Early Cinema and Juvenile Crime in Scotland: Edinburgh's Chief Constable at the 1917 Cinema Commission
}

\author{
JULIA BOHLMANN, University of Glasgow
}

\begin{abstract}
The enthusiastic relationship between children, adolescents and early cinema was observed with some unease in 1910s Britain. The Cinema Commission, set up by the National Council of Public Morals in 1917, was the first enquiry into the impact of cinema on children and young people in Great Britain and marks a significant moment in the modern discourse on children's media consumption and juvenile behaviour that is still on-going and transcends national boundaries. One of the Commission's key concerns was to investigate the link between the popularity of cinemagoing among children and rising juvenile delinquency. This article discusses in detail the contribution of Chief Constable Roderick Ross from Edinburgh to the Commission, who challenged the notion of such a link. The paper employs a historiographical research methodology, complementing the reading of Ross's statement with an analysis of the Scottish press and local municipal archival material. In that way it contextualises Ross's account in view of the distinct connotations of local censorship discourse in Scotland and reveals the ambiguities and complexity that it entailed.
\end{abstract}

\section{KEYWORDS}

Early cinema, children, juvenile crime, Scotland, 1917 Cinema Commission, censorship.

\section{Introduction}

Discourses on youth criminality and its suspected association with popular media originate in the second half of the nineteenth-century. So-called 'penny dreadfuls' - 'melodramatic novels about villains, pirates, highwaymen and thieves' (Beaven 2009, 106) - have been discussed as inspirational sources for juvenile delinquents ever since. When cinema arrived on the scene and emerged as one of the most popular pastimes during the 1910s, it was accompanied by similar anxieties. Only now fears intensified due to the dangerous and subversive conditions of many cinema halls - the use of inflammable nitrate films, crowdedness and darkness while films were shown, and, significant for this paper, the vividness of 'real-life' depictions on the screen (Beaven 2009; Kuhn 1988; compare also Grieveson 2004 and Rhodes 2012 on early cinema discourses in the United States). In regard to children and young people's behaviour, filmic representations of criminal acts such as bank robberies, assaults, stealing, stabbings and shootings were perceived by some contemporaries as a threat to be reckoned with (see Anon. 1916a and Anon. 1916b). 
impact of cinema on children and young people (NCPM 1917). While the Commission dealt with wide-ranging aspects related to cinema such as moral and physical problems (indecency, molestation, solicitation, eye-strain) as well as its educational potential, this paper will focus on the discussion of an alleged causal link between cinema and juvenile crime. To grasp the scale of this problem, the Commission invited chief constables from all over the UK to be heard at the Commission. The only one who went to London to give evidence in person was Chief Constable Roderick Ross from Edinburgh. It seems reasonable therefore to foreground Ross's contribution to the Commission in this article. Moreover, his account is worth detailed attention as it exposes the complexity of local censorship practices in Scotland at that time, offering a hitherto unexplored, non-central account of cinema, juvenile crime and regulation. In order to understand the significance of Ross's position in the local discursive context as well as in consideration of differing censorship practices in Scotland, it will be beneficial to situate it within a broader perspective. Firstly, I will look briefly at the academic debate regarding early cinema and the young as well as previous literature on the 1917 Cinema Commission.

There is a substantial academic literature on censorship and 'moral panic' around early cinema, and concerns regarding early cinema's influence on juvenile behaviour were not only articulated in Scotland and Great Britain but arose in other countries around the same time. In Policing Cinema, Lee Grieveson (2004) analyses the debate on nickelodeons - cheap store front cinemas - in the United States, especially Chicago, between 1905 and 1914. Nickelodeons were discussed by concerned reformers as spaces with the capability to undermine social and political stability. Grieveson identifies children's cinema patronage as the centre of this debate, because children began to be seen as 'citizens-in-formation' whose socialisation during childhood and adolescence was perceived as determinant of national health. (Grieveson 2004, 13 ff.). A similar discourse existed in Canada between 1908 and 1918; in Now Playing, Paul S. Moore demonstrates how stories of youthful thieves were worked into a broader rhetoric of a dangerous 'nickel madness' befalling independent children with pennies to spare and leading them into delinquency, which in turn called for the intervention by police and government (Moore 2008, 121-127). However, both studies not only focus on censorship debates but also discuss more forward-looking connotations of the moral discourse on early cinema. Grieveson, for instance, identifies a group of progressive reformers who were intrigued by the idea of developing cinema into a respectable social space in which 'uplifting' - propagandist and educational - films would be shown (Grieveson 2004, 23-24). Moore, meanwhile, deals with the debate on the establishment of a cinema in Weston, a suburb near Toronto, which was regarded by the Town Improvement Society as a potential vehicle for the modernisation of their community (Moore 2008, 117-21). In Europe, cinema's impact was just as eagerly discussed. Daniel Biltereyst, in his article 'Kruistocht Tegen Slechte Cinema' (Crusade Against Bad Cinema), refers to similar anxieties about the picture house in Belgium as well as the interfering actions of the Catholic church (Biltereyst 2007).

In October 1917, the National Council of Public Morals published The Cinema: Its Present Position and Future Possibilities in Great Britain. A few film historians as well as one film practitioner have engaged with this rich primary source, but their individual readings of the report vary. Film historian Jeffrey Richards (1984), for example, discusses the Commission's report in The Age of the Dream Palace in relation to the many 1930s inquiries undertaken to investigate cinema's impact on the young. Richards finds that, although many more surveys of this kind were embarked on then, the 1917 inquiry had already identified the three main concerns that 'continued to dominate discussions on the subject in the 1930s': 
the link between the cinema and juvenile crime, the effect on behaviour and attitudes and the physical effects of cinema-going. (Richards 1984, 79)

Brad Beaven's (2009) study of Leisure, Citizenship and Working-class Men in Britain, 1850-1945, on the other hand, places the 1917 Commission within the broader discourse on young male's leisure activities. The question was whether cinema or other leisure activities, such as football and street cycling, fostered or hindered the nurture of young boys into engaged citizens for the British Empire. Beaven claims that anxiety about juvenile leisure activities was nothing new at the beginning of the twentieth century, but that fears deepened due to changes in work patterns related to industrialisation and urbanisation. The popularity of cinema-going among working class young males was thus discussed as a consequence of the attainment of disposable income through semiskilled jobs and boredom at work due to repetitious tasks. In this context juvenile crime was regarded, on the one hand, as imitative behaviour absorbed passively from the cinema screen, but on the other as an expression of repressed masculine adventurism (Beaven 2009). ${ }^{1}$ In his book All Pals Together, film programmer and writer Terry Staples (1997) utilises the same primary source, but tells the Story of Children's Cinema, as his subtitle describes, from an audience perspective, using large extracts of interviews with children undertaken by the Commission. Staples finds that the analysis of children's views and statistical evidence taken together, ironically, testified that a great proportion of children 'never went to a cinema at all', deeming contemporary worries unjustified (Staples 1997, 18). He argues that the following four key themes determined the discourse about children's cinema since its beginning: 'exploitation, corruption, edification and diversion', the middle two figuring greatly in the 1917 Commission (Staples 1997, 1). More recently Paul Moody (2011) contrasted the 1917 Cinema Commission against contemporary police papers of London City Council. He finds that these papers show that prostitution and molestation of children were, indeed, serious, but often ignored problems there. Due to its size and social diversity, London can arguably be seen as an exceptional environment. The same issues may not have been as grave elsewhere in Britain and consequently not discussed with the same urge by the Commission. However, Moody argues that the Cinema Exhibitors Association (hereafter CEA) was instrumental in downplaying the issue in their testimonies to the Commission (Moody 2011). Such interference may have only been acceptable because of the CEA's alignment with the official war effort, as Michael Hammond and Michael Williams claim in their introduction to British Silent Cinema and the Great War (Hammond and Williams 2011, 7; also see Hammond 2006).

The academic debate on the 1917 Cinema Commission demonstrates that this source can be and has been interpreted in many different ways, depending on the research question, the social group and the location one's work is dealing with. So far it has focused on the English context, above all London. This article seeks to expand this body of work by contributing a historical case study on early cinema and juvenile crime in Edinburgh. It is based on a detailed survey of local primary sources that will be read alongside the Commission's report which is regarded as indicative of the broader national discourse. With Staples and Beaven, I argue that the 1917 Cinema Commission was a reaction to contemporary concerns regarding the alleged corruption of young people by the cinema. The Commission's main objective was to investigate the effects of cinema and to dispel unjustified assumptions regarding this. Whereas Moody focuses on the discussion of indecent behaviour within London's cinema halls, I will concentrate on the problem of juvenile crime and how it has been discussed as a result of cinema patronage from a Scottish perspective. While the problem of indecency in the cinema and obscenity on the screen was a noticeable part of the early

\footnotetext{
${ }^{1}$ See especially chapters three and five in Beaven 2009
} 
cinema discourse, I regard juvenile crime as the key issue when the effect of cinema on children and young people was contemplated. As will become further apparent below, when Edinburgh's Chief Constable discussed cinema as potentially harmful, he referred to film content rather than the cinema itself. For him cinema was not a dangerous place, which seemed to be the prevalent attitude in London, but a welcome alternative to the public house. Before I turn to Ross's statement, however, the next section will shed some light on the historical background in front of which the Cinema Commission appeared on the scene in 1917.

\section{Historical Context}

In 1916, two years into the First World War, the absence of many fathers, who had been recruited as soldiers, and mothers too, who replaced them in the workplace, was associated with progressively boisterous behaviour of young people and a statistical rise in juvenile delinquency. Without the unity of the family home, children were thought to be exposed to potentially immoral and harmful influences. The cinema was identified as one of these influences. An article on 'Juvenile Crime' in the London Times from May 1916 is representative of this fearful position towards the cinema. The article refers to a circular that had been issued by the Home Office to clerks of justices which stated that 'the total number of children and young persons charged with punishable offences has grown from 2686 to 3596' between December 1914 to February 1916 in seventeen large British towns (Anon. 1916a). The association with the cinema followed foot immediately: the Home Secretary, Herbert Samuel, stressed that most of the chief constables of these towns

represented that children are led to commit offences by witnessing cinematograph films depicting crimes, the use of firearms, $\&$ c, and that children often steal money in order to obtain admission to cinemas. (Anon. 1916a)

The lack of parental control and guidance in boys clubs due to war conditions as well as the lure of gaming machines were acknowledged factors contributing to the problem, but the cinema was the main target in this article. Accordingly, the article closed by referring to a 'resolution in favour of a central Government censorship of cinema films' adopted by the chief constables of England and Wales at a contemporaneous conference (Anon. 1916a).

The absence of Scottish chief constables at this conference indicates somewhat different legal conditions in regard to censorship practices north of the border, which I will discuss in some more detail below. It does not mean that Scots were not concerned about the effects of cinema-going on young people. The problem of rising juvenile criminality was represented along similar lines in a Scotsman article entitled 'The Juvenile Criminal' in November 1916. It concerned itself mainly with the problem in Edinburgh, where convictions of theft cases had risen from 243 in 1910 to 358 in 1915. Moreover, thieves often organised into gangs with such telling names as 'the Black Hand gang' or 'The Clutching Hand gang' inspired by popular crime serials. Especially social workers in contact with children claimed that picture shows offered a dual motive for the juvenile thief:

the creation of the desire to attend the picture shows and the suggestion in the film of means by which the necessary money might be obtained. (Anon. 1916b)

Some religious groups were also concerned and had taken action to control the impact of the cinema. The Glasgow Parish Council, for instance, had successfully lobbied the city magistrates to bring in legislation to restrict the admission of children in 1913 (NCPM 1917, 350). At the same time, it is, of course, important to recognise that the anxiety about cinema and the negativity of some commentators was by no means universal, and did not diminish its popularity or persuade the 
general public that it was a malign force. The author of the Scotsman article himself expressed a neutral attitude:

The cinematograph has been much indicted in regard to juvenile crime. In some respects it has been over-abused and certain of its critics have perhaps protested too much. (Anon. 1916b)

What this suggests is that more balanced and even optimistic positions existed that ran counter to anxious attitudes and newspaper reports emphasising cinema's potential to breed juvenile delinquents. Despite this, the discourse on early cinema's potential negative effects reached new heights when Herbert Samuel took several steps to introduce state censorship between May and October 1916. Sections of the cinema trade, especially the CEA, were dissatisfied with Samuel's proposal and started a public counter-campaign during the second half of that year (Kuhn 1988, 4243; Anon. 1916c). In an accompanying effort to raise the profile of the picture house, the Cinematograph Trade Council approached the National Council of Public Morals to conduct an investigation into the impact of cinema on children and young people, which resulted in the founding of the Cinema Commission (NCPM 1917, vii; Moody 2011, 58). Before dealing with the Commission and Chief Constable Ross's contribution to it, the distinct legal framework in Scotland and its consequences for the censorship discourse there will be considered next.

\section{Censorship Discourse and Local Regulation in Scotland}

Before 1909 British cinemas, and any other buildings in which film exhibitions took place, were subject to the same legal forces as music halls and theatres - the Disorderly House Act (hereafter DHA) of 1751. The DHA, however, did not account for the fire risk that the highly inflammable nitrate content of celluloid films represented to cinema staff and patrons, so a legal scheme was required that addressed this newly emerged problem. The answer was the 1909 Cinematograph Act, which required every house exhibiting films to take out a licence, granted by the county council or other local authorities when the instalment of certain safety regulations was confirmed. While mainly using the Act to implement fire safety regulations, some local authorities in England applied it also to ban film shows on Sundays or to prevent 'unwholesome' films from being exhibited. Exhibitors in England set out to dispute these bans in court, but the power of local authorities to intervene was reinstated by judges (Kuhn 1988, 15-16).

In Scotland, the prohibition of objectionable film exhibitions was debated, too. In 1910 for example, the Glasgow Magistrates Committee discussed whether to stop the screening of an interracial boxing match between the black heavyweight Jack Johnson and the white Jeffrey, the former winning the contest (Griffiths 2012, 60). However, another document regulating cinema exhibitions existed in Scotland - the Further Powers Act of 1892. Consulting this, Glasgow's town clerk recommended that 'once a licence had been issued, the authority had no right to intervene over the content of the show' (Griffiths 2012, 60). Accordingly, the Further Powers Act of 1892 enabled Scottish authorities to determine conditions and by-laws regarding cinema as a social space, but not to forbid film exhibition, signifying the Act's origins in a period when film shows did not yet exist. In 1913 for instance Glasgow Corporation had added a condition to cinema licences that prohibited the admittance of children without an accompanying adult to cinemas after 9:30 p.m. It also demanded that unaccompanied children that visited the cinema during the day were separated from the adults as well as trying to enforce efficient lighting throughout shows (NCPM 1917, 350). The 1909 Act, then, to use Trevor Griffiths' words, 
had not led to the assumption of censorship powers by Scottish licensing authorities, which remained for the most part content to limit their attention to issues of safety. (Griffiths 2012, 61)

The confinement of Scottish authorities to safety issues was not always to the satisfaction of local interest groups. In 1912 Edinburgh magistrates were criticised by local Presbyterians for their incapability to forbid the exhibition of the Passion play From the Manger to the Cross, a production by Kalem, disdained as exploitation of religious subject matter for entertainment and profit (Griffiths 2012, 60-61). In 1917, Edinburgh magistrates were pressured again into assuming censorship powers, suggesting that, when Ross appeared as a witness at the Cinema Commission, the censorship discourse in Scotland was ambiguous and far from being resolved (Edinburgh Magistrates 1917). Before looking at the discursive context in Edinburgh more closely, the following section will shed some light on the 1917 Cinema Commission.

\section{The 1917 Cinema Commission}

During the last two months of 1916, the Cinema Commission was swiftly established even though the immediate threat of state censorship subsided with the change from Liberal to Conservative government (Kuhn 1988, 42-45). This suggests that the NCPM had received the trade's request with some interest and perhaps even enthusiasm. A brief glance at the biographies of the two men leading the NCPM will help to outline this body's position.

Presbyterian James Marchant, who had founded the NCPM in 1911, had been previously involved with the National Vigilance Association (hereafter NVA), an organisation originating in the nineteenth century and active against prostitution, venereal disease, 'race degeneration' as well as the obscene in literary and visual representations (Bristow 1977, 142-143; Hunt 1999, 176-185). The NCPM shared some of this ground with the NVA, but was additionally influenced by the social scientific and ethical discourses around birth control ethics, the prevention of venereal disease and questions regarding good parenthood which emerged at the beginning of the twentieth century. Starting in 1913, the NCPM undertook a study of The Declining Birth Rate which was published in 1916 (NCPM 1916). Additionally, Marchant and the NCPM's president the Bishop of Birmingham (Henry Russell Wakefield) held an interest in popular entertainment and screen culture. The Bishop of Birmingham, for example, had campaigned to keep music halls and theatres open during the First World War, recognising the value of popular entertainment in raising civilian morale during distressful times (Parker 2012). Marchant had already realised the potential of the screen as a tool for propaganda during his employment at the NVA. As early as 1902 he had used films and lantern slides to support his campaigns for chastity (Hunt 1999, 176-177). The NCPM's ideological motives combined traditional evangelical beliefs with a modern social-scientific discourse. Moreover, its leaders were aware of cinema's potential to uplift and educate the public and, hence, drawn to investigating cinema more closely when the opportunity arose in 1916. It is not surprising then that Marchant and the Bishop both led the 1917 Cinema Commission.

The Commission as a whole transpired to be a diversely motivated body. It brought together four different factions of people interested in cinema, the NCPM being one of them. Secondly, the cinema trade itself, especially the CEA (represented by A. E. Newbould and W. Gavazzi King) and the Chief Censor T.P. O'Connor, were present on the Commission, aiming to raise the trade's profile. Thirdly, educationalists had a stake in cinema, showing an interest in developing it for the 
dissemination and memorization of knowledge. Finally, people more generally interested in child welfare formed a fourth group. Additionally, two famous personalities devoted their names and their time as cinema commissioners: General Lt. Baden-Powell (founder of the Boys Scouts) and Marie Stopes (author of birth control tract Married Love which was adapted for the screen and shown as Maisie's Marriage in 1923) (NCPM 1917, viii-ix).

The list of witnesses corresponds to this diversity of issues and interests. To begin with, some commissioners were additionally questioned as witnesses, for instance O' Connor, the two CEA representatives just mentioned, and eleven other people associated with the cinema trade, signifying the considerable proportion of influence the trade had on the Commission (NCPM 1917, xi-xii). One of the educationalists on the Commission, C.W. Kimmins, was asked to discuss his investigation into children's capacity to remember elements of films over a long period of time. Kimmins, next to Marchant and the Bishop, would become a prominent promoter of educational cinema during the 1920s and 1930s and was behind the follow-up report by the Cinema Commission, Cinema in Education, which was published in 1925 (NCPM 1917, 272-282). Significantly, the section of the cinema audience the 1917 Cinema Commission was mainly concerned with, school children (in groups of two or three at a time), appeared on the witness list, too. They were addressed mainly in regard to their film preferences, how often they went to the picture house and in what way it affected their well-being and motivation to do crime (NCPM 1917: 198-203, 209-10 and 243-44). The following is an extract of an interrogation of two London school boys, aged eleven and thirteen, by the Bishop, demonstrating the direct manner in which children were prompted to connect cinema with crime:

[D]o you like the comic films? - Yes, sometimes, if they are not too silly.

18. Do you consider Charlie Chaplin too silly? - Sometimes.

19. What about the love stories? - I do not think much of those

20. Do you like the films where people are stealing things? -Yes.

21. And where the clever detectives discovers them? - Yes.

22. Have you ever thought it would be a fine idea to copy these people and steal these things? -No.

23. Has it ever made you think what a fine sort of life it is to go round and break into people's houses? -No. (NCPM 1917, 200-201)

Certain specialists, such as an ophthalmic surgeon, a lighting engineer and a hygienist were called to testify on the effects of cinema shows. Furthermore, representatives of the police and judicial bodies were invited to attend the proceedings and give evidence, as were church leaders and organisers of religious groups like the Young Men's Christian Association, which had some experience with cinema in religious education. Finally, there were several personalities among the witnesses who opposed cinema. One such cinema-phobe was the well-known headmaster of Eton, Edward Lyttleton, who had published at length about the cinema. ${ }^{2}$ Miss Margery Fox from the Headmistresses' Union and Sir Robert Wallace, chairman of County of London Sessions, who were likewise critical towards the cinema, were interviewed by the Commission (NCPM 1917, xi-xii, 132-138, 138-142 and 151-156). There was at least one cinema opponent who decided that the

\footnotetext{
${ }^{2}$ For example in a critical Note on the Cinematograph alongside a pamphlet called The Child and the Cinematograph Show and the Picture Post-Card Evil in 1913.
} 
Cinema Commission was not a suitable platform for the expression of his opinion. Temperance reformer Frederick Charrington's doubts about the Commission's unofficial status were reported in the film trade paper Kinematograph Weekly just as it started its work in January 1917 (Anon. 1917a). Similar doubts were expressed again in April, when the Scottish MP, Sir Henry Craik, criticised the new Home Secretary, Gregory Cave, for not undertaking a government led investigation into cinema, instead tolerating a Commission that 'was largely organised by persons interested in the trade' (Hansard 1917).

The Commission invited and heard witnesses until June and published its final report in October 1917. The report is divided into several parts, each relating to different aspects of cinema such as its quality as a social space, film content and censorship, and finally film as an educational tool. In regard to the potentially negative impact of cinema, a distinction was made 'between moral evils incidental to the picture house and those consequential on the kind of film shown' (NCPM 1917, $\mathrm{xxv}$; emphasis in original). Moral concerns in connection to cinema as a social space focussed mainly on indecency (especially molestation of children and solicitation) suspected to be fostered by the darkness in which film shows were taking place. Physical impairments, such as eye strain caused by flicker and glare, were also discussed. Despite the prominence of its alleged negative aspects, cinema was acknowledged as an alternative social space to deprived working class homes, harmful streets, vulgar music halls and intemperate public houses. Furthermore, the report highlighted the educational assets of film, especially its appeal to the visual sense and how this could be exploited for educational instruction and propaganda. The problems related to currently available film content, however, seemed to outstrip all other aspects of cinema discussed in the report. One reason was that effects of film consumption on human behaviour were difficult to estimate and predict. Moreover, as an internationally circulating medium, the film text was less controllable and thus more threatening than problems associated with the space of cinema.

On the topic of juvenile crime, the report discriminated between incidental, 'thefts to pay for admission' and consequential delinquency, that is 'imitative crime' (NCPM 1917, xxxiv-xxxv). The charge of incidental crime was met with some measure of liberal common sense: 'There is nothing so peculiar to the cinema that only by its attraction are children led to pilfer' (NCPM 1917, xxxv). Penny dreadfuls, 'sweets, cigarettes, tram rides, music halls' were all equivalent attractions (NCPM 1917, xxxv). Moreover, it was acknowledged that preconceptions might play a significant role in creating false confessions: London probation officer John Massey, for example, warned 'that the statements of children as to why they stole [...][were] not to be taken too seriously, as sometimes these [...][were] suggested to them by others' (NCPM 1917, 218).

The charge of imitative crime being related to the pictures loomed somewhat larger. Sir Robert Wallace, chairing the county of London sessions, for example recalled several cases of juvenile delinquency that had followed upon cinema visits. This included the case of a seventeen-year old boy committing several burglaries and raising a value of about $£ 80$. Wallace stressed that the burglar visited the cinema 'almost daily' and that his circumstances 'exclude[d] any other motive' (NCPM 1917, xxxvi). Despite Wallace's evidence, Chief Constable Roderick Ross from Edinburgh appeared untroubled about the supposed link between cinema-going and juvenile crime. 


\section{Chief Constable Ross, the Cinema and the 'Bad Boys' of Edinburgh}

Ross appeared before the Cinema Commission on $12^{\text {th }}$ March 1917. The Bishop of Birmingham was in the chair. Ross was enthusiastic about the cinema, calling its emergence 'outstanding and remarkable' (NCPM 1917, 175). He rejected contemporary notions that cinema-going was only a temporary craze, arguing that, on the contrary, it had become 'part and parcel of [...] the social life of the community' (NCPM 1917, 175). Ross confirmed that in Edinburgh, with a population that he estimated to be between 320,000 and 330,000, there were 24 cinemas in 1917, with a seating capacity of 17,000 (NCPM 1917, 177). Furthermore, he stressed that the popularity of cinemagoing was not restricted to large towns like Edinburgh, but included rural communities and attracted all social classes:

Not only in large towns but in country districts the cinema has met with phenomenal success, and received the support and patronage of all classes of society. (NCPM 1917, 175)

Ross's statement contradicted assumptions about cinema's association with urban lower class life. He explained cinema's all-encompassing popularity in terms of public approval of it as 'educative, morally wholesome, and bright entertainment,' but also as a consequence of its low admission price (NCPM 1917, 175). That it had an immense 'influence either for good or evil' was beyond doubt for Ross. However, he was sceptical about the emphasis on its negative potential:

Were the lessons it taught to exercise an influence for evil in the people, that evil would ere now have made itself manifest in some form or other. (NCPM 1917, 176)

Instead the Chief Constable stressed 'its power for good in the community' (NCPM 1917, 176). In Edinburgh, he said, it attracted many people 'who otherwise would have resorted to the publichouse' (NCPM 1917, 176). This was confirmed also by his district officers. That cinema rivalled the public house was not new for Ross. He had made a note of this as early as 1911 in his Annual Report, from which he read an abstract to the Commission:

I am more than convinced that people are behaving themselves better than formerly, and I am of opinion [...] that the gradual decrease in drunkenness has been brought about by the opening up to the people of more means of rational amusement such as the picture house. (NCPM 1917, 183)

It is noteworthy that Ross referred to cinema as rational entertainment when critics of cinema blamed it for providing just the opposite - an entertainment that did not contribute to educating young people into engaged citizens, but instead gave ample opportunity to waste their time and money on visual pleasures. (Beaven 2009). ${ }^{3}$ This criticism was not unique to cinema but originated in nineteenth-century discourses on other forms of popular entertainment. Ross's comment indicates that cinema's function was still far from being determined and that there was hope for developing it into an edifying and, indeed, rational form of recreation.

Regarding the negative social impact of the emergence of cinema, the Chief Constable had received 'few complaints [...] as far as Edinburgh is concerned' (NCPM 1917, 177). Ross pointed out that those complaints referred not to the cinema as such, but to the pictures exhibited there. He stressed, furthermore, that he and his police force did not act solely on private individuals' complaints but

\footnotetext{
${ }^{3}$ Compare especially chapter two in Beaven 2009 (44-88), on 'The era of mass leisure: the pleasure seeking citizen, $1870-1914$ '.
} 
considered interference with objectionable films only appropriate if there was 'criticism in the Press' (NCPM 1917, 181). Ross's position met with some perplexity among the commissioners, so that he was eventually prompted to state his personal opinion about a controversial picture (the title of which was omitted in the final report) and the corresponding 'actions being taken in Manchester' in regard to its exhibition:

[Y]ou would not regard it as a film suited for general display? - No, were I a censor I should certainly ban it for young people under eighteen or twenty years of age. (NCPM $1917,181)$

The disparity between the Constable's own opinion and his lack of power to interfere with the exhibition of 'objectionable' films caused even more confusion. Some of the commissioners went on to ask more detailed questions - for instance Reverend F.C. Spurr, who enquired more directly about the police's authority to seize photographs, prints and films:

39. Have the Edinburgh police the power to seize objectionable prints and photographs? -- Yes, any objectionable or indecent.

40. But you have not the power to seize objectionable films? - If the films were indecent we should not seize them, but we should proceed against the management.

(NCPM 1917, 182)

Ross's assessment of the core problem - the cinema being a potential source of inspiration for juvenile delinquents - was similarly ambiguous. Ross found that, regardless of some objectionable pictures, no case of imitative crime had so far 'come to [...] [his] knowledge or to the knowledge of [...] [his] detective officers' (NCPM 1917, 176). He admitted, however, that screen representations of criminals implied a 'grave danger,' especially to boys due to their 'inherent love of adventure' (NCPM 1917, 176-77). In regard to incidental crime, stealing in order to afford admission to the cinema, Ross was 'unable to find a single case where any juvenile set out to steal for this one purpose' (NCPM 1917, 177). He found that thieving in order 'to satisfy their fondness or craze for gambling' was far more common among young delinquents of the Scottish capital (NCPM 1917, 177). Ross thus concluded that,

so far as Edinburgh is concerned, the cinema, in this respect and as a means of inciting the commission of crime on the part of juveniles, has had little or no effect on the crime committed by children and young persons. (NCPM 1917, 177)

Read against the cross questioning of the Cinema Commission as well as local references, Ross's account seems to throw up more questions than it answers. Was the ambiguous and uninvolved attitude of the Chief Constable a particular feature of the Edinburgh police force at that time? Or did he merely state his own personal approach? While these questions are valid and point out areas where further inquiry is necessary, I suggest that Ross's statement and questioning hinted at the complexity of regulatory practices in Scotland which as mentioned above differed to those in England.

Considering the Scottish regulatory framework with its self-imposed restriction to regulate cinema space and not to impede with film exhibition, Chief Constable Ross and his police force's lack of involvement with censorial issues seems plausible. Nonetheless, three months after Ross's statement as a witness to the Cinema Commission, Edinburgh magistrates were compelled to take control over local censorship practices. Minutes taken from an Edinburgh Magistrates Committee 
meeting in June 1917 reveal that they had received representations 'on the subject of the control or censorship of films exhibited in licenced Picture Houses' (Edinburgh Magistrates 1917). The magistrates acted upon these complaints and instructed the Burgh Engineer, the authority responsible to issue annual licences to Edinburgh cinemas, to act as censor especially in picture houses that catered for children:

[I]n future they [the magistrates] will expect the licensee of Picture Houses, especially in cases where the entertainment is mainly frequented by children, to exercise particular care to ensure that no film will be shown which may be offensive to public feeling or injurious to morality or incite to crime or which may tend to have an evil influence on the minds of children. (Edinburgh Magistrates 1917)

What this reflects, of course, is that the magistrates as elected officials were answerable directly to the electorate, obliged to change the law if necessary, whereas Ross was appointed head of police, simply following the law and coercing others to follow it. The complaints the magistrates received might have expressed long lingering concerns of Edinburgh citizens regarding cinema and juvenile crime, simply ignored or taken too lightly by the Chief Constable. Or the complaints were a direct reaction to Ross's sanguine statement at the Cinema Commission, which subsequently appeared in form of short synopses in the national and local press, possibly spurring local pressure groups into action (Anon. 1917b; Anon. 1917c; Anon. 1917d).

A glance at Edinburgh newspapers from 1917 suggests that Ross's carefree attitude could have been at odds with public opinion. In the Edinburgh Evening News the Chief Constable stressed repeatedly that 'we cannot accuse the cinema of inciting its juvenile patrons to crime', implying that blaming the cinema was a common practice he tried to contest (Anon. 1917b). Moreover, not all Scottish chief constables adopted the same neutral approach. While letters to the Cinema Commission testify that the chief constables of Aberdeen, Dundee and Glasgow in broad terms agreed with Ross's account, Chief Constable Thom of Hawick, a small town in the Scottish borders, expressed a different viewpoint (NCPM 1917, 178-79 and 350). For him there was 'little room for doubt that the desire of many young people to obtain money to attend picture houses, billiard saloons, and ice cream shops had been the cause of a large number of the juvenile offences that the police had to deal with' (Anon. 1917e). This indicates that, despite Ross's alacrity to dispel concerns regarding juvenile crime and to support the cinema, its potential to cause delinquency among children and young people was an eagerly debated topic in Edinburgh and Scotland. In addition, although the legal framework discouraged authorities to carry out censorship, which finds expression in Ross's account to the Commission, the inclination to do so existed in Edinburgh in 1917.

\section{Conclusion}

This article has explored the discourse on early cinema and the young, focusing on a key problem the assumption of a causal link between cinema patronage and juvenile crime. It approached the 1917 Cinema Commission by the NCPM from a Scottish perspective, analysing the contribution of Edinburgh's Chief Constable Roderick Ross, who argued against such a link. The article discussed Ross's account in view of regulatory practices and censorship debates in Scotland and highlighted the intrinsic ambiguities.

In the context of the Cinema Commission, Ross played a significant role. It should be noted that it is unknown whether the Commission had chosen Ross over other UK chief constables to testify in 
person or whether he was the only one who was motivated enough to appear as a witness. The Chief Constable of Glasgow, for example, was invited, but declined (Corporation of Glasgow 1917). Like other chief constables who responded to the Cinema Commission, he provided information in form of a letter, the more common response to investigations like this. I argue that Ross's personal presence bore somewhat more weight than the letters that other constables sent, not to speak of constables that did not respond to the Commission at all. ${ }^{4}$ Ross played a key role in influencing the opinions of the commissioners, trying hard to dispel anxiety regarding cinema's potential to cause juvenile crime and at the same time highlighting its value in keeping people away from the public house.

The Cinema Commission concluded that a link between cinema patronage and juvenile criminality was not 'a necessary connection, and not exclusive of many other factors too often ignored' (NCPM 1917, xlvii). However, that films were powerful, capable of giving children 'wrong ideas of life and conduct' more generally, turned out to be a serious worry for the cinema commissioners even while a direct link between cinema patronage and youth criminality remained unproven. Particularly condemned were shooting and stabbing scenes and the tendency of some films to present an 'enlarged view of the victim's features during death agony' (NCPM 1917, xlii). In the end, such scenes were deemed 'highly objectionable to children, whether they lead to delinquency or not' (NCPM 1917, xlii). As a result, the Commission advocated central state censorship as a more reliable practice than local authority censorship that was to ensure a higher and unified standard of film exhibition all over the UK. This recommendation was never realised.

In regard to a causal link between cinema patronage and juvenile crime, neither Ross nor the 1917 Cinema Commission had the last word on the subject. Despite the respectability of the NCPM and the high profile membership of the Cinema Commission, the validity of the report and even the formation of the Commission itself were repeatedly interrogated. The refusal of Frederick Charrington to take part in it and Henry Craik's speech in the House of Commons exemplified these doubts early on. Shortly after the report's publication, the Commission was again accused of partiality by a member of the Home Office, who claimed that it had been financed by the cinema trade (Anon. 1917f). The Commission's unofficial status, related and repeated attacks on it, might have contributed to its failure to create a closure on the question. Instead allegations against cinema as a source of inspiration for juvenile delinquents recurred frequently, especially during the 1930s when multiple surveys on cinema and juvenile crime were undertaken throughout Britain, including one investigation that focussed on Edinburgh alone - The Edinburgh Cinema Enquiry from 1933 (Richards 1984, 68ff.). So even in Edinburgh, where Ross's positive statements about the cinema were repeatedly published in local newspapers, an official inquiry was found necessary sixteen years after the first Cinema Commission.

Ross's account of cinema and juvenile crime cannot be regarded as representative for Scotland or even Edinburgh. While other Scottish chief constables agreed with his position in broad terms, we also know of Chief Constable Thom of Hawick, who supported the notion that children's cinemagoing habits were connected to a rise in juvenile delinquency. Furthermore, a closer look at municipal records disclosed that Edinburgh had a history of interest groups pressuring the magistrates to perform cinema censorship, especially in cinemas visited by children in 1917. Rather than signifying a unified Scottish position, Ross's statement is, thus, symptomatic of a disparity

\footnotetext{
${ }^{4}$ The Commission received 118 responses which were attached to the final report, constituting Appendix III, pages 333 372 .
} 
between the legal and the public discourse on early cinema, censorship and the behaviour of young people in Scotland. When prompted, Ross admitted his personal disapproval of a film, but referred to the limitation of his authority that enabled him to seize objectionable photographs and objects, but not to ban films. This, I argued earlier, indicates the distinctiveness of the censorship discourse and legal practice in Scotland, which was somewhat different to the English situation. In regard to cinema regulation, Scottish authorities had two legal documents to adhere to, the 1909 Cinematograph Act and the Further Powers Act of 1892. Whereas the Cinematograph Act could and was used by authorities in England to interfere with the exhibition of films, Scottish authorities restricted themselves to issues of physical safety. The Further Powers Act was interpreted in a way that did not allow for a licence to be taken away once it had been granted by the authority.

Nonetheless, this article has also revealed that, despite its limits, the Scottish regulatory framework contained opportunities to go beyond basic orders. Since cinema licences had to be renewed annually, Edinburgh magistrates were able to instruct their Burgh Engineer to withhold licences for picture houses that exhibited objectionable films while being frequented by children. As a result, the Edinburgh magistrates were acting upon unofficial efforts by sections of their electorate to extend their authority and protect children from objectionable film content whereas Chief Constable Ross merely voiced the official, legal position on cinema and censorship in Scotland at that time. The broader question of how far the extension of power to censorship went in practice in Scotland between 1910 and 1927 is a question still requiring historians' attention, and, as this article has demonstrated, the ambiguities and importance of individual personalities in the surrounding discourse make further careful mining of the local archives a promising avenue.

\section{References}

Anonymous (1916a) 'Juvenile Crime. Home Office Advice to Justices. A Film Censorship', The Times, 13 May, 3

--- (1916b) 'The Juvenile Criminal. Lack of Parental Control', Scotsman, 11 November, 11

--- (1916c) 'Mr. Samuel Offers a Bad Bargain. Soothing Syrup which does not Soothe. What Is the Secret Meaning of the Censorship Proposals?', Bioscope, 26 October, 334-35

--- (1917a) 'Mr. Fredk. N. Charrington Declines to Give Evidence before the Kinematograph Commission', Kinematograph Weekly, 4 January, 22

--- (1917b) ‘Edinburgh's Crime - The Juvenile Depravity - Chief Constable’s Explanation', Edinburgh Evening News, 10 March

--- (1917c) 'Boy Burglars and the Cinema', Glasgow Evening Times, 14 March

--- (1917d) 'State Cinema Censorship. The Recommendations of the Commission of Enquiry', Scotsman, 10 October, 11

--- (1917e) 'Cinemas and Crime', Edinburgh Evening Dispatch, 10 January, p. unknown

--- (1917f) 'Who are our Traducers? A Lie and its Author. Who Dare Question the Impartiality of the Cinema Commission?', Bioscope, 15 November, 4

Beaven, B. (2009) Leisure, Citizenship and Working-class Men in Britain, 1850-1945, Manchester: Manchester University Press 
Biltereyst, D. (2007) 'Kruistocht Tegen Slechte Cinema: De Katholieke Filmactie En Bioscopen', in D. Biltereyst, De Verlichte Stad, Houten: Lannoo Campus, pp. 142-161

Bristow, E. J. (1977) Vice and Vigilance: Purity Movements in Britain since 1700, Dublin: Gill and Macmillan

Corporation of Glasgow (1917) 'Magistrates Committee Scroll Minutes', 25 January

Grieveson, L. and American Council of Learned Societies (2004) Policing Cinema Movies and Censorship in Early-twentieth-century America, Berkeley: University of California Press

Griffiths, T. (2012) The Cinema and Cinema-going in Scotland, 1896-1950, Edinburgh: Edinburgh University Press

Edinburgh Magistrates Meeting Book (1917) 'Magistrates Committee Full Minutes', 11 June Hammond, M. (2006) The Big Show: British Cinema Culture in the Great War, 1914-1918, Exeter: University of Exeter Press

Hammond, M. and Williams, M. (2011) 'Goodbye to all that or business as usual? History and memory of the Great War in British cinema', in M. Hammond and M. Williams (eds), British Silent Cinema and The Great War, Houndmills, Basingstoke: Palgrave Macmillan, pp. 1-16

Hansard (1917) 'Digitised Editions of Commons and Lords: Hansard, the Official Report of Debates in Parliament 1803-2005', 2 April, [online]. Accessible at http://hansard.millbanksystems.com/commons/1917/apr/02/cinema-commission. Accessed 1 October 2013

Hunt, A. (1999) Governing Morals: A Social History of Moral Regulation, Cambridge: Cambridge University Press

Kuhn, A. (1988) Cinema, Censorship and Sexuality, 1909-1925, London: Routledge

Moody, P. (2011) “"Improper Practices” in Great War British Cinemas', in M. Hammond, and M. Williams (eds.), British Silent Cinema and The Great War, Houndmills, Basingstoke, Hampshire; New York: Palgrave Macmillan, pp. 49-63

Moore, P. S. (2008) Now Playing : Early Moviegoing and the Regulation of Fun, Albany: State University of New York Press

National Council of Public Morals (1916) The Declining Birth-rate. Being the Report of and the Chief Evidence taken by the National Birth-Rate Commission, Instituted, with Official Recognition, by the National Council of Public Morals - For the Promotion of Race Regeneration - Spiritual, Moral and Physical, London: Chapman and Hall Ltd.

--- (1917) The Cinema, Its Present Position and Future Possibilities. Being the Report of and Chief Evidence Taken by the Cinema Commission of Inquiry Instituted by the National Council of Public Morals, [online], London: Williams and Norgate. Accessible at http://archive.org/stream/cinemaitspresent00natirich. Accessed 1 October 2013

National Council of Public Morals (1925) The Cinema in Education: Being the Report of the Psychological Investigation Conducted by Special Sub-committees Appointed by the Cinema Commission of Enquiry Established by the National Council of Public Morals, London: Unwin Brothers of London and Woking/NCPM.

Parker, S. G. (2012) 'Wakefield, Henry Russell (1854-1933)', in Oxford Dictionary of National Biography, [online], Oxford University Press. Accessible at http://www.oxforddnb.com/view/article/70369. Accessed 1 October 2013

Rhodes, G. D. (2011) The Perils of Moviegoing in America: 1896-1950, New York: Continuum 
Richards, J. (1984) The Age of the Dream Palace: Cinema and Society in Britain 1930-1939, London: Routledge \& K. Paul

Staples, T. (1997) All Pals Together: The Story of Children's Cinema, Edinburgh: Edinburgh University Press 